\title{
Community, connectivity and the regional movement in Patagonia: the evolution of social capital in the Aysén Region of Chile
}

\author{
John W. Durston, José Manuel Gaete and Miguel Pérez
}

ABSTRACT

AUTHORS
KEYWORDS

JEL CLASSIFICATION
Small rural communities in the Aysén Region of Chile evince a variety of forms and types of social capital. The predominant form of social capital has evolved in accordance with changes in the national context and the gradual integration through communications. Having been an example of community cooperation, rural communities were faced with the challenge of relating to more powerful social actors on the broader stage of the region's civil society. This change often resulted in autonomy declining and community factions being caught up in chains of clientelism. In 2012, however, the "Your problem is my problem" movement emerged to address the marginalization perceived in the region's asymmetrical relations with central government. The mass civil disobedience this involved was grounded in three types of social capital and marked the emergence of a citizenship that spanned the region, thus meeting one of the conditions for fully democratic decentralization.
Rural development, social capital, community development, community participation, Internet, Chile

Z130, R580, R500

John W. Durston holds a Ph.D. in Anthropology from the London School of Economics and Political Science.1johndurston@gmail.com

José Manuel Gaete is a postdoctoral researcher with the National Fund for Scientific and Technological Development (fondecyt) and the Centre for Regional Development and Public Policy Studies (ceder) of the Universidad de Los Lagos, Chile. josemanuel.gaete@ulagos.cl

Miguel Pérez is a professional with the Innovation for Competitiveness Fund/MA in Public Policy and Management, Division of Planning and Regional Development (DiPlade), Regional Government of Aysén. mperez@goreaysen.cl 


\section{I}

\section{Introduction}

Social capital is an intangible resource developed by individuals and collective actors to bring their projects to fruition, not just in traditional communities but in modern societies as well. Its basic attributes of trust, diffuse reciprocity and cooperation go against the principles of the market, but they are actively involved in this, as well as in civil society.

For more than two decades, the concept of social capital has attracted the attention of academics and policy designers because of its implications for economic development and governance. Research and proposals have centred on two aspects: the importance of networks in people's strategies, and the potential for small communities to apply this intangible asset in their strategies as actors in the market and in civil society. The present case study concentrates on the interaction between these two forms (personal and collective) of social capital in the field of civil society, combining information from the academic literature on social capital, civil society and social movements with empirical information on the Aysén Region.

Two main questions are addressed in this article: which forms of social capital have predominated at different times in the Aysén Region, and what implications the forms of social capital involved in the recent regional movement have for decentralization. The ultimate goal of the methodology applied is to capture the role of social capital in an emerging civil society at the regional level.

A selection was made of seven rural communities that exemplified a variety of degrees of isolation (see table 1) and geographical and population characteristics. In them, a survey was applied ${ }^{1}$ to 493 Internet users, with an estimated omission rate of less than $5 \%$. Each household was visited up to three times on successive

$\square$ This article is part of National Fund for Scientific and Technological Development (FONDECYT) project No. 1120866, "El impacto de Internet en el capital social de las comunidades aisladas."

1 The Survey of Rural Internet Users was carried out during 2012 as part of this research in the small communities listed in table 1. days and all users who had accessed the Internet in the previous week were interviewed.

A cluster analysis methodology was applied to Internet users aged over 25. The technique employed to develop this classification is a two-stage cluster analysis that works by dividing a given number of cases into a set of groups where: (i) one case corresponds to one group only, and (ii) the set of groups contains all the cases covered by the classification. For these conditions to be met, the distance/difference within groups must be smaller than the distance/difference between groups, which means obtaining a silhouette coefficient of 0.6 or higher in the case of the two-stage classification.

The qualitative instruments and strategies of grounded theory (an inductive sociological method) were applied. With this method, instead of independent and dependent variables being defined (excluding the rest of the information from the environment), open interviews based on very general research questions are used. Hypotheses emerge as information is accumulated, without any pretension of "proving" them. The process of repeated comparison, hypothesizing and fieldwork also involves critical scrutiny of the theoretical literature. The last stage of the research project concentrates the efforts to generate new interpretations of theoretical value or potential use in public policies, always keeping a very close eye on the empirical data.

The practices, relationships and processes detected through these qualitative techniques exemplify phenomena that can provide a basis for interpretative models, but do not represent the quantitative scale a phenomenon may have in the total population. Accordingly, the qualitative information was collated with the numerical data, from which new hypotheses about the relationship between connectivity and social capital emerged.

The article is structured as follows. After this Introduction, section II deals with the debates, definitions and diversity surrounding social capital. Section III examines connectivity and community social capital in isolated areas of Aysén. Section IV focuses on the regional movement and the role played by social capital and the Internet in this context. Lastly, section V contains the main conclusions drawn from the study. 


\section{II}

\section{Social capital: debates, definitions and diversity}

Interpersonal relationships and sociocultural organizations embody social capital when they turn norms of reciprocity, identity and solidarity into practices of cooperation and mutual assistance. By dint of repetition, these practices reinforce such norms, while increasing trust among the people involved. Taken together, these facets of social capital open the way to endeavours in all kinds of fields, making it more likely that goals beyond the reach of individuals acting alone can be attained.

During the last decade of the twentieth century and the first five years of the present one, the debate on the concept of social capital spread throughout the world of social policy. It even took hold among a wider public, with the success of the book Making Democracy Work (Putnam, 1993). It also took on a probably excessive importance in discussions about participatory development and poverty reduction, with heights of hyperbole being reached in cases such as the World Bank publication arguing that social capital might be the "missing link" in development (Grootaert, 1998). For most analysts, the fact that grass-roots social actors possessed these collective capabilities was a reason to reinforce this intangible resource by allocating more public resources to self-managed group endeavours.

Until then, even the relevance to development of the topics of associativity and cooperation had been in doubt, partly because of the axiomatic assumption in economic models that actors sought to maximize their individual gains. Hardin reinforced the argument against the possibility of cooperation and collective action in a modern market system: in his 1968 work The Tragedy of the Commons, he argued that the individual interest of each actor ensured the depletion of common economic resources, such as communal grazing areas. The publication of Governing the Commons (Ostrom, 1990) changed many minds.

Elinor Ostrom, the only woman to have been awarded the Nobel Prize in Economics, analysed thousands of cases of community management of common goods and ultimately cast doubt over Hardin's theoretical arguments. As Uphoff (2003) puts it, Ostrom's work serves "to explain the great many collective actions that do in fact occur and endure." Ostrom's studies take full account of individuals' rational choice, and thus emphasize the role of rules in sustainable collective management to avoid this being betrayed when individuals are tempted by the prospect of personal gain. However, they also take account of people's feeling that they are shaping their own destiny and of the cultural norms that bestow prestige on behaviours that serve the group.

\section{Two types of social capital}

One of the main ways in which social capital manifests itself is the creation of civil society organizations (Putnam, 1993; Molenaars, 2006). Another is the formation of extensive networks of personal ties, which also influence civic life (Portes, 1998). These are two different ways in which people participate in the civil society of their community and country. Their interaction largely determines the role of different forms of social capital in the direction taken by civil society in a given territory.

The distinction is important, since personal social capital consists in a reciprocal or dyadic link between two people and the networks these links create, while the collective takes on more organized forms, with division of labour, legitimation of leaders and social oversight of members. In each concrete case, interpersonal ties and loyalties can mean that a grass-roots organization works better when the resources to which these provide access are placed at the disposal of the collectivity by the individual. However, these personal links can also mean that these organizations' resources are diverted to pettier goals, damaging trust in the collectivity. The separation of the two concepts is an advance, since definitions of social capital in the early 1990s (Putnam, 1993, for example) mixed different levels of analysis (values, practices, outcomes) and did not distinguish between different forms of social capital.

\section{Organizations}

The earliest formulations of social capital as an analytical category, dating back about a century, focused on its collective communitarian form. The great educational theorist John Dewey also inaugurated the theoretical and academic use of the term in the late nineteenth century (see Farr, 2004). In his writings and those of one of his followers, Lyda Hanifan, a clearly collective definition is expounded: 
"[social capital is] good will, fellowship, sympathy, and social intercourse among the individuals and families who make up a social unit, the rural community... this social capital may easily be directed towards the general improvement of the community well-being" (Hanifan, 1920).

Not every formal organization has a high level of social capital, which is an intangible and informal asset. In many "paper" organizations, the partners' practices do not follow informal standards of solidarity and honesty. Nor are informal groups lacking clear formal rules stable over time. Ostrom teaches that formal organization is needed in order for social capital to cope with greater management goals, as well as to exclude free-riders through rules setting out who the members are and what rights they have and laying down progressive sanctions against rule-breakers, depending on the seriousness of the transgression (Ostrom, 1990).

The ramifications and limits of collective social capital have become clearer as empirical studies pile up and analyses are made (Atria, 2003), so that it has become established as one of the key concepts in a new analytical framework of "grass-roots development." Nonetheless, social capital is just one asset among many that individuals and collectivities possess and employ in strategies to improve their social position.

Social capital has other important aspects: it is always an asset for its possessors, but is not always good for society at large. It is now clear that power is a key link in this conceptual framework that was "missing" for many scholars of the subject in the 1990s. Elites' use of their personal networks to exclude large sections of the population from decision-making on matters of public interest was studied in France, in great empirical and theoretical detail, by Pierre Bourdieu. That author developed his concept of "social capital" in the 1970s (Bourdieu and De Saint Martin, 1978). His view of the subject encompassed aspects not considered by Hanifan, or by Putnam afterwards. Bourdieu and his followers relate social capital to the struggle between different networks of business or bank owners and high-level public officials to control fields of power. The relevant terms of his wide-ranging and dispersed model of social capital also include, for example, shared patterns of behaviour based on experience (habitus) which reinforce class identities, inherited relationships, cultural and educational capital (classmates) and modes of domination
(Bourdieu, 2001). Its importance at this point is that it requires the notion of social capital as a "resource for the poor" to make way to one of social capital as a resource in the competition between all actors. In this model, civil society and the State are shot through with ties between allies and struggles between rival groups to control the field of public policy.

This conception, which incorporates the inequality of power, draws a distinction between actors occupying similarly powerful social positions, with "symmetrical" or "horizontal" ties, ${ }^{2}$ and asymmetrical social capital, such as political clientelism, linking people who are unequally placed.

Simply put, political clientelism is the trading of "favours for votes," but it has other important facets that make it a form of social capital: (i) linkage between individuals, and (ii) its function as an "upward" extension of traditional microlocal mutual assistance networks among the grass roots. In summary, clientelism is a "personalized" (Auyero, 2001), "asymmetrical" and "inter-class" form of social inclusion for individuals and communities whose position is that of subalterns (literally "the others below"). Like all other ties of interpersonal social capital, clientelism is symbolically reinforced by gestures of (real or simulated) friendship (Wolf, 1966). It also helps unprivileged strata gain access to (mainly public) resources controlled by privileged ones. There is a great variety of roles and relationships associated with different situations of political clientelism, ranging from the role of "boss" to that of "semi-clientelist reformist" (Fox, 1996).

Lastly, a distinction is drawn between "active" grass-roots social capital and "submerged" social capital, which survives in latent form as a social memory when the conditions in the environment are inhospitable to it (Salazar, 2001).

The present study uses a number of these dichotomous concepts of social capital: personal and collective, active and submerged, symmetrical and asymmetrical. The study in the Aysén Region sheds light on some aspects of this conceptual and empirical complexity in contexts of growing integration and connectivity.

\footnotetext{
2 Also known as bridging social capital, because it links pairs of different groups or localities (Woolcock and Narayan, 2000).
} 


\section{III}

\section{Connectivity and community social capital in isolated areas of Aysén}

The Aysén Region, in Chilean Patagonia, is one of the country's 15 administrative and electoral regions. Aysén is characterized by low population density, a cold, rainy climate, extensive forests and rugged terrain. Taken together, these conditions configure a geographical space that is difficult to traverse and inhabit, and also to connect up.

The purpose of this section is to better understand how the progressive reduction in isolation has contributed to changes in the forms of social capital predominating in rural communities of the Aysén Region (see table 1).

TABLE 1

Degrees of isolation of the communities studied in the Aysén Region

\begin{tabular}{ll}
\hline Quintile & Communities \\
\hline 1 (most isolated 20\%) & Villa O’Higgins \\
2 & Lago Verde, Puerto Tranquilo \\
3 & Villa Amengual, Caleta Tortel \\
4 & Puerto Ibáñez, Cerro Castillo \\
5 (least isolated 20\%) & ------ \\
& Universe $=52$ inhabited localities
\end{tabular}

Source: Prepared by the authors, on the basis of Office of the Undersecretary for Regional and Administrative Development (SUBDERE), "Metodología para la identificación de localidades en condición de aislamiento", Santiago, 2013 [online] http://www.subdere. gov.cl/sites/default/files/documentos/metodologia_03072013.pdf.

The seven communities range in size from about 300 to 800 inhabitants each. They also exemplify a variety of geographical and economic variables.

The term "connectivity" is often used to refer to the rapid exchange of information via computers and other new media such as mobile phones. These are the so-called "modern" information and communications technologies (ICTS). Here, though, the term is used in a broad sense to include not just the Internet but also "traditional" ICTs (radio, telephone, television) and all forms of territorial integration (carriage of messages, people and goods by land, water and air); in short, all techniques that reduce isolation.

It will now be contended, first, that the increase in broadly defined connectivity has affected community (i.e., collective and local) social capital in rural areas in varying ways, and has reduced the historical isolation of the region; second, that rural communities in Aysén have been experiencing this process continuously for at least half a century; third, that personalized and asymmetrical forms of social capital have replaced many of its community forms in the field of civil society; and lastly, that the development on the region's territory of a critical mass of grass-roots organizations, together with the interaction of traditional and modern ICTs, made it possible for a successful regionwide social movement to arise.

The first contention sets out from theoretical arguments and empirical evidence from other countries. Wellman (2001) argues, first, that the spread of the telegraph and other inventions in the nineteenth century freed communication from the constraints of transport; second, that most people in Canada and the United States relate more now through extra-community networks than with other local residents; and third, that these changes are causing people to feel less engaged with their communities, leaving these with less control over their behaviour, while feelings of belonging, membership and identity with the local group have been weakening. The Internet, in particular, has increased the opportunity, contingency and uncertainty of interpersonal relationships relative to the old context of local groups.

The first formulations of community social capital were produced in the United States almost a century ago. Hanifan (1920) noted with concern that the railway, the telegraph, the telephone and the automobile had hastened the rural exodus in the period after the First World War, weakening the social fabric of rural communities. In the face of the challenge posed by the progressive disappearance of rural community activities, Hanifan proposed the development of a complete strategy of community centres to reconstruct communities' impaired social capital. Although there is a huge gap between the situation in Aysén and that in the United States formerly, the near-universal tendency towards the disappearance of many rural communities due to the expansion of connectivity is well known. This evolution differs between communities in Aysén, but it should be noted that these have experienced the impact of ICTs from a century ago (telephone, radio) and the ICTs of the twenty-first century almost simultaneously, in a swift, intense transformation. 


\section{IV}

\section{Social capital and connectivity:} periods and transitions

During the last 50 years, the development of connectivity and the transformation of social capital in Aysén can be divided into three periods corresponding to improvements in connectivity and changes in the relationship between the region's rural communities and central government.

\section{(a) The period from 1964 to 1973}

By about 1964 (the start of the reformist administration of the Christian Democracy party), the State had already established basic connectivity for the region in the form of road, river, sea and air transport and postal and telephony services (Martinic, 2005). Radio spread as soon as electricity became available (initially from car batteries or miniature water turbines). The radio quickly became the main channel for information, personal messages and real-time conversation. ${ }^{3}$ In the 1960 s, horse trails were gradually widened into cart tracks, which were used by the first motor vehicles (Universidad de Los Lagos/ Centre for Social Network Analysis, n/d).

Even accounting for the near-universal sentiment that "the past was always better," the in-depth interviews clearly revealed how many solidary ventures were undertaken a generation ago within each community studied. The practice of free, collective school-building for example, is historically documented. When money was needed for some community venture, fund-raising dances used to be held and attended by people from other communities as much as two days' travel away. Young people from the different communities in each microregion met at such dances and formed couples. Now such events only involve local people and are held when a resident needs help with medical expenses or after a fire, but the old ways left a network of kinship in the region's communities (Universidad de Los Lagos/ Centre for Social Network Analysis, n/d). In the five communities studied, according to the Survey of Rural Users, $34 \%$ of users were born in a different commune in the Aysén Region. Each community, then, has ties of kinship across the region.

\footnotetext{
3 Short-wave radio, an "old" technology compared to mobile telephony or the Internet, created the conditions for subjectivity in dialogue in Aysén more than half a century ago.
}

In Aysén, like everywhere else in the country, this was a period of major changes in rural communities: the agrarian reform under the governments of Eduardo Frei Montalva and Salvador Allende, unionization and ideological polarization in civil society. Catholic and left-wing organization proposals competed to set up neighbourhood associations and committees of small farmers (through the National Institute for Agricultural Development (INDAP)) and to register voters. Many inhabitants of rural communities in Aysén benefited from agrarian reform and the extension services for rural cooperatives fostered by these two administrations.

The connectivity of the 1960s improved the ability of the State to empower rural communities by formalizing their rights and providing advisory services to them as organizations. The committees of small farmers set up by the idealistic early extensionists of INDAP took on a variety of social action roles, as local residents and not just as farmers. The collective social capital of small communities was supplemented and also complicated by the growing presence of asymmetrical forms not just of political clientelism, but also of more solidary manifestations of social capital.

\section{(b) Asymmetrical ties of solidarity}

The idealistic extensionists and officials of the agrarian reform programme of 1964-1973 allied themselves with the inhabitants of rural communities in Aysén, acting from higher social positions in the field of State-rural relationships. The wool commercialization cooperatives supported by INDAP at that time are still part of social memory in the communities studied by the aforementioned National Fund for Scientific and Technological Development (FONDECYT) project. The personal relationships between local leaders and professional extensionists connected these leaders with the directors of the regional offices and with the parties in government at the regional and central levels. The sense of mission driving many of these extensionists led them to place their contacts at the service of local leaders, who gained in prestige as they were able to help improve the quality of life of their entire community (Astorga, 2007; Universidad de Los Lagos/Centre for Social Network Analysis, n/d). 
(c) The period from 1973 to 1989

Agrarian reform was cut short after the military coup of 1973, while the rest of that decade and the whole of the next were marked by the military presence throughout the region at different levels of the State and civil society. In Aysén, telecommunications were a key factor in "internal security" and in the defence against a possible Argentine invasion. They also ensured the virtual absence of opponents of the de facto government in the region's civil society organizations. In addition to physically eliminating many activists, the State promoted the creation of residents' associations whose leaders were adherents of the regime. These helped decide on the distribution of goods, this being also a new and important role for the mayors appointed by the head of State.

Chile's Route 7, also known as the Carretera Longitudinal or Carretera Austral (it was originally named after President Augusto Pinochet), was an emblematic contribution by the army to the region's connectivity and served as an emigration route for many impoverished settlers and a way in for forestry, fisheries, transport and tourism companies. As of around 1970, there were some 1,000 kilometres of public highway. The expansion work was begun by the Military Labour Corps in 1976. Including the network of side roads, 1,283 kilometres were built between 1976 and 1989, taking the total to 2,300 kilometres. The road network is now about 3,500 kilometres long.

The military government divided up the region into a larger number of communes and appointed mayors in these as it sought to increase support for its geopolitical strategy in Chilean Patagonia, ${ }^{4}$ but at the same time the initiative for collective action in the communities of Aysén was lost and a welfarist relationship began in which social capital was asymmetrical and people held positions of power because of their relationship with the central State:

"... a lot of subsidies were given during the dictatorship, and there were all sorts of handouts, especially family food baskets. So people gradually got used to going to meetings just to ask for or collect subsidies..." (Resident of a rural Aysén community, in Astorga, 2007).

\footnotetext{
4 The army remains an important actor in the region, owing to the geopolitical concept of effective sovereignty: "The army's role in cooperating with the development of isolated and outlying areas... has been an issue of constant concern... We need to improve our ability to control empty spaces, since otherwise some other actor or threat will tend to occupy them or capitalize on this" (Commander-in-Chief of the Army, in Ejército de Chile, 2013).
}

The second half of the 1970s was a time of discouragement in the rural communities of Aysén, ${ }^{5}$ since the policy of severely reining in the economy and employment as a shock treatment for inflation coincided with a collapse in the world price for wool, a crisis from which sheep farmers in Aysén never recovered. As a result, an exodus began in the early 1980s as people left the region in search of employment and education.

As new firms came in, trade unionism re-emerged, clandestinely at first, as a grass-roots actor with collective social capital, particularly in the fishing sector. In general, though, the period of the dictatorship resulted in the destruction of social capital, both personal (with the loss of trust) and collective (because of the repression of organizations). For the rural world in Aysén, then, this was eminently a period of "submerged" social capital (Salazar, 2001).

\section{(d) The period from 1990 to 2013}

The ending of the military dictatorship following the 1988 plebiscite opened the way to free elections and grass-roots associativity. Conditions improved for unions and local organizations and more resources were made available by the central State for community organizations, partly through the elected mayors. However, this expansion of civil society was guided by the parties in the two main electoral coalitions, which have alternated in power in recent years.

There was further expansion of the road network, air transport and television and radio broadcasters, and modern ICTs such as mobile phones began to spread. Thanks to low handset prices (subsidized by the telecommunications firms), use of these expanded quickly, especially from 2010, as new transmission masts were built.

As for the Internet, a number of communities had had at least an Internet café or community centre with a satellite or fixed modem service for several years. With the advent of mobile telephony, though, computer owners could use a $3 \mathrm{G}$ signal to connect to the Internet from their homes or workplaces.

In the years following the dictatorship, the personalized asymmetrical relationship of solidarity between the community and vocation-driven officials was developed by the young professionals of Servicio País (Universidad de Los Lagos/Centre for Social Network

\footnotetext{
5 One exception was Father Antonio Ronchi, considered by respondents to be another driving force in community organization, as he encouraged the formation of local organizations to create communications infrastructure using local resources. Among many other projects, his was the predominant advisory role in the construction of satellite television antennae by the community.
} 
Analysis, n/d), a programme of support for mostly rural municipalities. The sense of mission of many of these functionaries led them to place their contacts at the service of local leaders. The personal relationships between these leaders and the professionals connected the former with the people responsible for running a number of public services in the region. Local leaders gained in prestige insofar as they were instrumental in improving quality of life for all residents.

\section{(e) Clientelistic links}

The presence of State agencies has not always meant more social capital and greater power for rural communities in Aysén. Electoral clientelism is neither a new phenomenon nor peculiar to Aysén, but universal in representative democracies. Leaders with contacts and allies in the political parties and State bureaucracy were viewed by their neighbours as friends who could solve the problems they encountered with different public services (Auyero, 2001). Leaders of a "managing" type are brokers (Valenzuela, 1977) who deal with requests through these vertical links. The negotiations they enter into to solve local problems engage communities' voting intentions. Unlike vocation-driven extensionists, political brokers do not usually empower grass-roots organizations so much as enhance their own political careers.

Although lack of connectivity limited the penetration of clientelism in the early period of isolated communities, by 2012-2013 mayors were the brokers most often mentioned (Universidad de Los Lagos/Centre for Social Network Analysis, n/d). They could give public-sector jobs to their followers or, more subtly, appoint their officials as advisors who would help to draft good applications to development funds for communities whose leaders could assure them of their votes (Universidad de Los Lagos/Centre for Social Network Analysis, n/d). In Puerto Tranquilo and Puerto Bertrand, both small inland communities, Astorga (2007) found that:

"People group together and make their needs known to the leader, who is responsible for speaking to the authorities and conveying the community's concerns. This gives the leader a new role and power within the community, as the person able to put the community in touch with 'higher' circles" (Astorga, 2007).

In 2013, the qualitative research detected more clientelist leaders than participatory leaders accountable to the grass roots. The survival of certain traditional forms of participation clashed with the increase in clientelistic relationships. These two opposing forms of social capital in the rural communities of Aysén translated into growing divergences between those living there. (f) The impact of the Internet on rural communities

Although most of the rural Aysén communities studied only received large-scale access to the Internet in 2011 or 2012, by the latter year there were already indications of at least four changes in social capital that can be related to this ICT.

First, according to the respondents, people tend to spend more time at home communicating with each other via Facebook, so that there is less face-to-face contact:

“... the tradition of going to each other's houses, drinking mate and talking about everyday things started to be lost because of this opportunity to communicate digitally" (Universidad de Los Lagos/ Centre for Social Network Analysis, n/d).

Second, mobile phones and the Internet offer a way to create autonomous and independent economic connections with the outside.

Third, this technology can make residents less dependent on the leaders who were formerly the brokers between them and the wider world, as they can directly access information that was once the preserve of wellconnected leaders. Many people can now establish their own social capital links, both horizontally with distant peers (bridging capital) and vertically with public officials and other more powerful people. This broad empowerment is beginning to reduce the asymmetry in relationships of political clientelism.

It is not that there is less social capital in the region now than formerly, but that the social capital produced by modern ICTs is not usually communitybased but personal (for the same phenomenon in other countries, see Foth, 2003, and Ferlander and Timms, 2007). It is not surprising, then, that in 2013 just $48 \%$ of all Internet users participated in local organizations. Within this general trend, however, respondents fall into three clusters differing clearly in behaviour and attitudes:

(i) participants only (they do not use the Internet, but tend to participate in local organizations);

(ii) Internet users (they are frequent users of the Internet but participate less in local organizations. They tend to be younger and better educated than people in the other two clusters).

(iii) participatory Internet users (they are frequent users of the Internet and also participate in local organizations).

Thus, for example, $93.3 \%$ of participatory Internet users (who are about a third of all users) agree with the proposition "I feel part of the community," which is a higher share than for the other two clusters (see table 2). 
TABLE 2

Indicate agreement or disagreement

\begin{tabular}{|c|c|c|c|c|c|}
\hline \multirow{2}{*}{ Disagree } & & \multicolumn{3}{|c|}{ I feel part of the community } & \multirow{2}{*}{ Total } \\
\hline & & Disagree & Neither agree nor disagree & Agree & \\
\hline \multirow{4}{*}{ Participants } & Number & 4 & 2 & 51 & 57 \\
\hline & $\%$ row & 7.0 & 3.5 & 89.5 & 100.0 \\
\hline & $\%$ column & 11.8 & 6.9 & 18.8 & 17.0 \\
\hline & Corrected standardized residuals & -0.9 & -1.5 & 1.8 & \\
\hline \multirow{3}{*}{ Internet users } & $\%$ row & 18.2 & 12.6 & 69.2 & 100.0 \\
\hline & $\%$ column & 85.3 & 69.0 & 40.4 & 47.5 \\
\hline & Corrected standardized residuals & 4.7 & 2.4 & -5.3 & \\
\hline \multirow[t]{4}{*}{ Participatory Internet users } & Number & 1 & 7 & 111 & 119 \\
\hline & $\%$ row & 0.8 & 5.9 & 93.3 & 100.0 \\
\hline & $\%$ column & 2.9 & 24.1 & 40.8 & 35.5 \\
\hline & Corrected standardized residuals & -4.2 & -1.3 & 4.2 & \\
\hline \multirow[t]{3}{*}{ Total } & Number & 34 & 29 & 272 & 335 \\
\hline & $\%$ row & 10.1 & 8.7 & 81.2 & 100.0 \\
\hline & $\%$ column & 100.0 & 100.0 & 100.0 & 100.0 \\
\hline
\end{tabular}

Source: Universidad de Los Lagos/Centre for Social Network Analysis (n/d), "Documentos de trabajo internos", FONDECYT Project (No. 1120866), "El impacto de Internet en el capital social de las comunidades aisladas", Santiago.

\section{(g) From clientelism to the social movement}

To summarize, social capital in the rural communities of Aysén has undergone major changes over the last half-century. Although the different specific forms of social capital have been present at all times, some have weakened while the presence of others has increased. These tendencies seem to be connected to the progressive integration of isolated communities into national society and to changes in central government orientation. In civil society, there has been an increase in clientelistic relationships with political leaders. The most common effect where collective social capital is concerned has been for communities to become increasingly divided into factions (Universidad de Los Lagos/Centre for Social Network Analysis, n/d; Astorga, 2007). At the personal level, though, the net effect seems to have been an increase in networked social capital spanning greater geographical and social distances. Nonetheless, horizontal networks and collective forms of social capital continued to exist in a "submerged" (latent) form. This persistence was crucial to the success of the regional movement of 2012 .

\section{$\mathrm{V}$}

\section{The "Your problem is my problem" regional movement: the role of social capital}

In early February 2012, an organization of artisanal fishermen invited other organizations to a meeting in Puerto Aysén to suggest they present a united front in their demands (Miranda and Morales, 2012). That meeting led on to a series of marches, barricades and demonstrations by thousands of people in the streets of towns and villages that paralysed the whole region for over a month. The speed with which the "Your problem is my problem" social movement emerged took the central government by surprise, and its reaction was to use the police to suppress it. Eventually the government was obliged to negotiate and to accept many of the movement's demands.

The regional approach has been virtually forgotten in the debate about social capital, despite being the cornerstone of the book that unleashed the avalanche of studies and debates. In Making Democracy Work (1993), Robert Putnam argued that the Emilia-Romagna Region of 
Italy was a successful case of decentralization, with regional democratic management of public resources, because it had a society endowed with plentiful social capital.

The few studies on social capital and regionalist movements in Latin America include, first and foremost, the study by Fox (1996) of various regions of Mexico. Fox traces the route by which a grass-roots regional movement is forged from community social capital. More recently, Cortés and Sinisterra (2009) have explored the relationship between social capital, social movements and good governance in the Cauca region of Colombia, while Burbano de Lara (2012) has compared the movements for autonomy in Santa Cruz in the Plurinational State of Bolivia and Guayaquil in Ecuador, focusing on the social capital of regional oligarchies.

Aysén's is a “contentious" movement (Tarrow, 1998), i.e., one intended to create a contention with the State, an impasse that will force the latter to meet its demands and listen to its proposals. This contention developed as a joint evolution of these two actors' strategies to the point where doubt was cast over the State's ability to fulfil its role as guarantor of the conditions (such as transport routes, basic services and public order) for economic life in this territory. By mounting an illegal general strike and using barricades to close public highways, the movement broke the established rules and started a "game of the rules." ${ }^{6}$ The government employed a strategy of violent repression, and the movement implemented a communications strategy of displaying this violence, thus eliciting a great deal of support from Chilean and international public opinion.

The specialist literature helps to establish and separate the analytical categories of social capital and social movement. Cortés and Sinisterra (2009) argue that a social movement is a very different phenomenon to social capital: a movement is a collective action that may have a great deal of social capital or little. Again, the Aysén movement differs from those of Santa Cruz and Guayaquil in that these were largely initiated by regional "oligarchies" (Burbano de Lara, 2012) with populist discourses. The "Your problem is my problem" movement in Aysén, by contrast, grew out of and was mobilized in the region's grass roots. The emerging hypothesis is that, with the consolidation and success of this movement, a regional social actor emerged that drew in all subaltern sectors.

6 The main leader, however, successfully stood for a seat in the national Chamber of Deputies in 2013. This departure from and return to the "rules" meant an advance in the democratization of political life in Aysén.
The field study identified three aspects of this movement in which social capital played a role: existing regional organizations (collective social capital), networks among leaders (interpersonal bridging social capital) and Patagonian social memory ("submerged" social capital).

(i) Organizations. The 2012 regional movement was able to mobilize a great many people quickly in part because it was initiated by a number of organizations with informal collective social capital, i.e., informal rules and effective accountability practices at the grass roots. The unions of artisanal fishermen and workers in fisheries firms, the organization combating the hydroelectric macroproject, hauliers and public-sector employees, having each mounted major mobilizations on their own account, also committed heavily to the strike and demonstrations in this common cause. ${ }^{7}$

The project this study forms part of was implemented in a sample of seven communities chosen with a view to exemplifying the diversity of the kinds of isolation found in the region, whose organizations, each acting by itself, had successfully held strikes, demonstrations and negotiations in earlier years. Their goals also differed radically from one another's, something that has also been characteristic of other social movements in Latin America (De Sousa Santos, 2001). In January 2012, though, the leaders of a number of organizations began to meet to explore areas of convergence regarding the region's situation (Universidad de Los Lagos/Centre for Social Network Analysis, n/d). In sum, the fact that there were already organizations with collective social capital was a determinant in the success of the regional movement.

(ii) Personal horizontal networks between leaders. Data on Aysén from 2006 indicated that over 70\% of people claimed to have personal support networks in case of need (ILPES/GORE, 2012). And, as has been seen, residents of rural communities usually have ties of kinship across the region.

At the regional level, this same horizontal type of bridging social capital among the main leaders of "Your problem is my problem," who were personally known to one another, constituted an interpersonal network even before the regional movement arose (see figure 1). The interviews conducted with various regional leaders indicated that networked social capital, with closed or overlapping mutual recognition among these leaders, can

\footnotetext{
7 These organizations exist to negotiate with the State. This is obvious in the case of the public-sector employees' association, but it is also true of the artisanal fishermen's unions (the original kernel of the movement), created as a result of incentives in the Fisheries Act to negotiate fishing quotas with the National Fisheries Service (SERNAPESCA).
} 
largely explain why the mobilization spread so quickly.

(iii) Submerged social capital. This concept refers to social capital that was developed in the past and remains latent. The "social memory" of earlier generations" experiences is kept alive and organizational capabilities once employed in the old communities are transmitted (Astorga, 2007):

"The community goes through long periods of lethargy and inactivity [but] when faced with an external threat it temporarily resumes a proactive role" (Universidad de Los Lagos/Centre for Social Network Analysis, n/d).

Another form of submerged social capital is the always latent ability to mobilize around a socio-territorial goal. There is still a clear Aysén and, more broadly, Patagonian identity, associated with the fact of having been born in Patagonia and sharing an array of norms and values. This is a collective identity process that rests on the distinction between us and the others (Barth, 1969). People born in the region exclude "incomers" who are not Patagonian and also those who do not practise the pioneer habitus of generosity, reciprocity and solidarity, i.e., "the rich." The alterity is clear:

"[Outsiders] come with a good standard of living... they come here and start to live in the centre, they form a circle where everyone is a professional... they cut themselves off totally and completely from the local people... so it's like two worlds existing side by side" (Universidad de Los Lagos/Centre for Social Network Analysis, n/d).

The contention, then, is that these three forms of submerged social capital, namely the social memory of collective action, inter-community and inter-organization interpersonal networks and the collective Patagonian identity, all contributed to the strength of the "Your problem is my problem" movement.

FIGURE 1

Network of contacts between leaders before January 2012

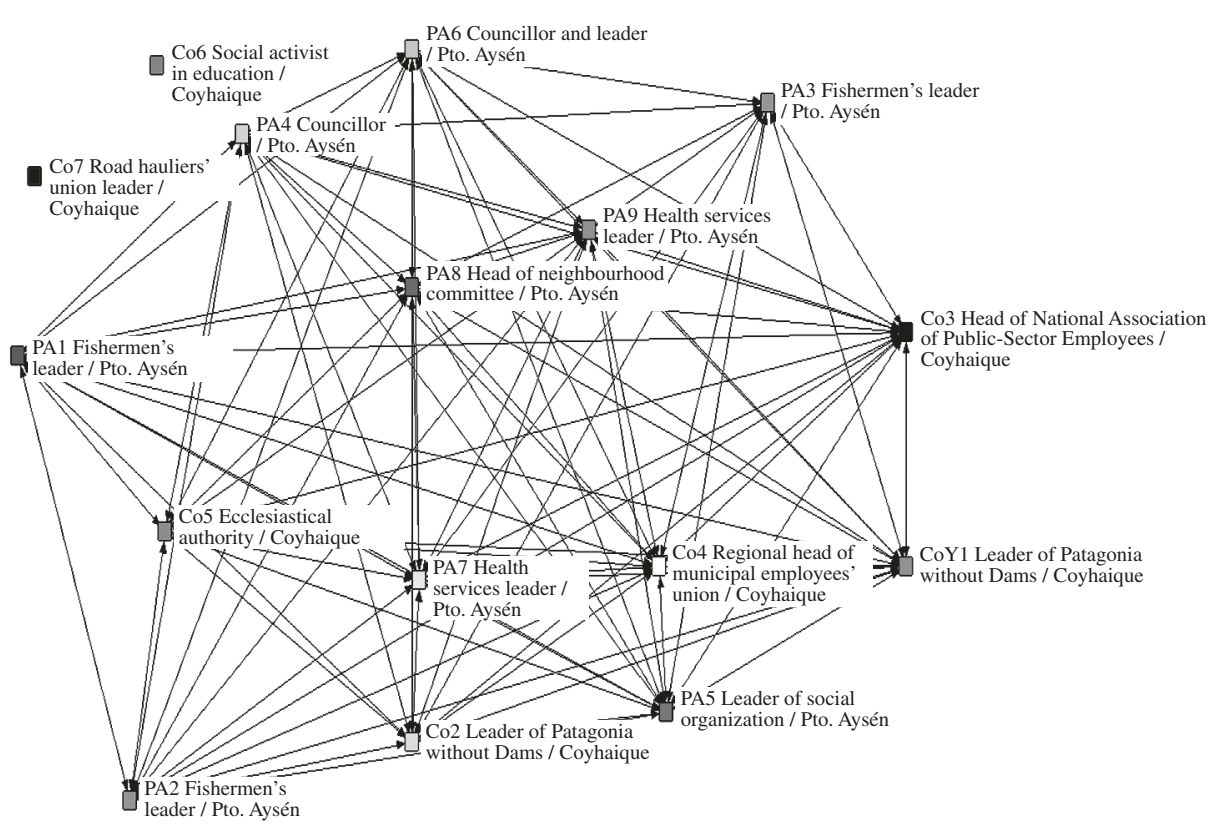

Source: Prepared by the authors, on the basis of interviews and the social network analysis method processed using the UCINET software.

\section{The role of the Internet in the movement}

The Internet is unquestionably the technology with the greatest potential for the advancement of social movements based on networking. Even in the 2009-2011 period, the Internet was crucial in the effort to coordinate and finance "Patagonia without Dams," a major anti-hydroelectric movement regionally, nationally and internationally
(Astorga, 2013). Partly because Internet coverage in the countryside was still incipient, however, in 2012 rural residents learned of "Your problem is my problem" mainly from the radio, which played the central role in creating broad support:

"Here there are a lot of people living in the countryside who have to get their news from a battery radio... the radio has always been very important for ordinary 
people and for social leaders" (Universidad de Los Lagos/Centre for Social Network Analysis, n/d).

Nonetheless, the Internet did play a twofold role in the success of the movement. First, $41 \%$ of participatory Internet users in rural communities participated in or supported social movements via the Internet, which was almost double the rate for "pure" Internet users (see table 3). Furthermore, $100 \%$ of this subset of residents participate in local organizations. In sum, participatory Internet users provided a link between two levels of collective social capital: that of the local community and that of regional organizations.

TABLE 3

How often do you use the Internet and participate in or support social action?

\begin{tabular}{|c|c|c|c|c|}
\hline & & Never & At least sometimes & Total \\
\hline Participants & $\begin{array}{l}\text { Number } \\
\% \text { row } \\
\text { Corrected standardized residuals }\end{array}$ & $\begin{array}{r}51 \\
89.5 \\
3.1\end{array}$ & $\begin{array}{c}6 \\
10.5 \\
-3.1\end{array}$ & $\begin{array}{c}57 \\
100.0\end{array}$ \\
\hline Internet users & $\begin{array}{l}\text { Number } \\
\% \text { row } \\
\text { Corrected standardized residuals }\end{array}$ & $\begin{array}{r}119 \\
77.3 \\
1.7\end{array}$ & $\begin{array}{l}35 \\
22.7 \\
-1.7\end{array}$ & $\begin{array}{l}154 \\
100.0\end{array}$ \\
\hline Participatory Internet users & $\begin{array}{l}\text { Number } \\
\% \text { row } \\
\text { Corrected standardized residuals }\end{array}$ & $\begin{array}{l}69 \\
59.0 \\
-4.2\end{array}$ & $\begin{array}{r}48 \\
41.0 \\
4.2\end{array}$ & $\begin{array}{l}117 \\
100.0\end{array}$ \\
\hline Total & $\begin{array}{l}\text { Number } \\
\% \text { row }\end{array}$ & $\begin{array}{l}239 \\
72.9\end{array}$ & $\begin{array}{l}89 \\
27.1\end{array}$ & $\begin{array}{l}328 \\
100.0\end{array}$ \\
\hline
\end{tabular}

Source: Universidad de Los Lagos/Centre for Social Network Analysis (n/d), "Documentos de trabajo internos", FONDECYT Project (No. 1120866), "El impacto de Internet en el capital social de las comunidades aisladas", Santiago.

Second, young professionals with Internet experience gained with "Patagonia without Dams" played a key role in developing media capacity for the "Your problem is my problem" regional movement. Artisanal fishermen's leaders are low-income workers and knew little about the Internet. The movement's early communications initiatives consisted in going to the local radio stations and sticking up posters on walls in Puerto Aysén calling on people to join in the first march. Within a few days, though, the support of "Patagonia without Dams" for the new movement meant there could be a qualitative leap in impact on national public opinion.

“... [T] hat was a tremendous contribution to the movement by 'Patagonia without Dams'... They know the media, so they would take what we said and send it [over the Internet] to different newspapers..." (Universidad de Los Lagos/Centre for Social Network Analysis, n/d).

The main national media tended to reprint government press releases and gave little space to the movement's complaints about police violence, for example. However, use of all the resources of the Internet, from e-mail to blogs and Facebook, led to the movement's messages going viral among users of these virtual social networks. Facebook in particular proved a good channel for influencing public opinion with videos of police repression and interviews with leaders.

But the Internet was not the only communications tool vital to the movement's success: there was a complex dynamic of interaction between traditional ICTs (radio, television, newspapers) and modern ones, while the use of Twitter (the microblogging Internet application used to send short messages that can go viral among huge numbers of users) on mobile phones made it possible (i) to coordinate a rapid mobilization of the movement in response to repressive tactics, and (ii) to communicate the movement's demands, support for the strike and police repression to the country and the world:

"... the police were throwing bombs and all that, and that came out through Facebook [from people] who were in there online or with iPhones and stuff, and we [on the radio] were picking up on a lot of that information... there was nothing on the telly, so what a lot of pressure was applied by this humble medium!" (Universidad de Los Lagos/Centre for Social Network Analysis, n/d). ${ }^{8}$

\footnotetext{
${ }^{8}$ The live webcast by Radio Santa María in Coyhaique was followed by regional, national and international journalists and activists.
} 
In summary, despite the incompleteness of Internet coverage in rural communities of Aysén and the digital exclusion of low-income strata, it was thanks to this interaction between media and technologies that the

\section{VI}

\section{Conclusions}

By distinguishing between different types of social capital, this study has been able to develop new hypotheses about its evolution in the Aysén Region and its role in changes within civil society. This article has presented a historically and socially grounded review of the different forms of social capital that flourished in four stages of the development of the region's civil society. Different types of social capital have come to the fore successively as transport and communications connectivity has grown, during different periods of central government public policy.

More than 50 years ago, at a time when communities were very isolated and the presence of the State was limited, the composition of social capital was dominated by horizontal networks that reinforced collective community actions. These networks were subsequently weakened as all forms of collective capital were co-opted or repressed. With the return to electoral democracy, there was an upsurge in clientelism; finally, from 2012, the different forms of submerged social capital were reactivated by a regional movement.

The 2012 movement does not seem to have been a one-off, but marks a watershed in Aysén civil society and in the forms of social capital sustaining it. Although its effect on public policy was limited the first year (Pérez, 2014) and the movement returned to a relatively "submerged" state, regional grass-roots organizations continued to press their demands and the central State, together with the national Congress, laid the foundations for a State policy for this and other "outlying areas". Within the framework of a new law for these regions, the public budget for Aysén was increased by $67 \%$ from the 2012-2015 period (Universidad de Los Lagos/Centre for Social Network Analysis, n/d).
Internet played a key role in the ultimate success of the regional movement, enhancing communication both with local actors and with national public opinion by supplementing traditional ICTs.
The contentious movement in Aysén is a case deserving of consideration and comparison, firstly because it is a case of bottom-up participation not dominated by "regional oligarchies," and secondly because it marked a transition from actors with social capital "in" the regional territory to a grass-roots actor "of" the territory at the regional level. Although there were already local and regionwide organizations with collective social capital, the 2012 movement led to the emergence of a broad-based subaltern social actor with a regional presence, capable of counterbalancing actors in more powerful social positions.

The relevance of an analysis of the different forms of social capital to the implementation of electoral and administrative decentralization is now beyond doubt:

" ... the more social capital there is to buttress their legitimacy, grounded in relations of loyalty and/or trust in them on the part of social organizations, the better chance these actors will have of playing a proactive role in any decentralized process" (De la Maza, Cunhill and Joignant, 2012).

Putnam (1993) showed, in the case of Italian regional decentralization, that social capital matters to the outcome of this process, as the general welfare is enhanced when it is present while inequality is exacerbated when it is absent. In the light of the Aysén experience, the authors of the present study suggest that this approach can be applied to other regions that benefit, potentially at least, from decentralization. The lessons of Aysén, whose civil society has been successfully democratized, provide clues to the way the social capital of potential subaltern collective actors can be enhanced as an integral part of decentralization. 


\section{Bibliography}

Astorga, E. (2013), "Conflicto ambiental en Patagonia: observaciones sobre la comunicación medioambiental en la región de Aysén a raíz del proyecto Hidroaysén", thesis, Santiago, University of Chile.

(2007), "Puerto Guadal y Puerto Bertrand: una mirada antropológica hacia la historia de las relaciones sociales que hoy en día generan una escasa participación de las personas en proyectos de desarrollo local", thesis, Santiago, University of the Academy of Christian Humanism.

Atria, R. (2003), "Capital social: concepto, dimensiones y estrategias para su desarrollo", Capital social y reducción de la pobreza: en busca de un nuevo paradigma, Libros de la CEPAL, No. 71 (LC/G.2194-P), R. Atria and others (comps.), Santiago, Economic Commission for Latin America and the Caribbean (ECLAC).

Auyero, J. (2001), La política de los pobres: las prácticas clientelistas del peronismo, Buenos Aires, Manantial.

Barth, F. (1969), "Introduction", Ethnic Groups and Boundaries: The Social Organization of Culture Difference, Oslo, Universitetsforlaget.

Bourdieu, P. (2001), Las estructuras sociales de la economía, Buenos Aires, Ediciones Manantial.

Bourdieu, P. and M. de Saint Martin (1978), "Le patronat", Actes de la recherche en sciences sociales, vol. 20-21, No. 1, Paris, Seuil.

Burbano de Lara, F. (2012), "Movimientos regionales y autonomías políticas en Bolivia y Ecuador", thesis, University of Salamanca [online] http://gredos.usal.es/jspui/bitstream/10366/115574/1/ DDPG_Burbano_de_Lara_F._Movimientos_Regionales.pdf.

Cortés, R. and M. Sinisterra (2009), "Colombia: social capital, social movements and sustainable development in Cauca", CEPAL Review, No. 99 (LC/G.2418-P), Santiago, December.

De la Maza, G., N. Cunhill and A. Joignant (2012), "La descentralización: asunto de actores y su articulación", Nueva agenda de descentralización en Chile: sentando más actores a la mesa, G. de la Maza, N. Cunhill and A. Jognant (eds.), Santiago, RIL Editores.

De Sousa Santos, B. (2001), "Los nuevos movimientos sociales", Observatorio Social de América Latina, No. 5, Buenos Aires, Latin American Social Sciences Council (CLACSO).

Ejército de Chile (2013), "Presidente de la República clausuró Seminario sobre zonas aisladas y soberanía efectiva" [online] http://www.defensa.pe/forums/showthread.php/5413-Noticiasdel-Ejercito/page37.

Farr, J. (2004), "Social capital: a conceptual history", Political Theory, vol. 32, No. 1, SAGE Publications.

Ferlander, S. and D. Timms (2007), "Social capital and community building through the Internet: a Swedish case study in a disadvantaged suburban area", Sociological Research Online, vol. 12, No. 5 [online] http://www.socresonline.org.uk/12/5/8.html.

Foth, M. (2003), "Connectivity does not ensure community: on social capital, networks and communities of place" [online] http:// eprints.qut.edu.au/1902/1/1902.pdf.

Fox, J. (1996), "How does civil society thicken? The political construction of social capital in rural Mexico", World Development, vol. 24 No. 6, Amsterdam, Elsevier.

Fukuyama, F. (2003), "Capital social y desarrollo: la agenda venidera", Capital social y reducción de la pobreza: en busca de un nuevo paradigma, Libros de la CEPAL, No. 71 (LC/G.2194-P), R. Atria and others (comps.), Santiago, Economic Commission for Latin America and the Caribbean (ECLAC).

Grootaert, Ch. (1998), Social Capital: The Missing Link?, Washington, D.C., World Bank.
Hanifan, L. (1920), The Community Center, Boston, Silver, Burdette \& Co. Hardin, G. (1968), "The tragedy of the commons", Science, vol. 162, No. 3859 .

ILPES/GORE (Latin American and Caribbean Institute for Economic and Social Planning/Regional Government of Aysén) (2012), Estrategia regional de desarrollo de Aysén, Santiago, Economic Commission for Latin America and the Caribbean (ECLAC).

Martinic, M. (2005), De la Trapananda al Aysén. Una mirada reflexiva sobre el acontecer de la Región de Aysén desde la prehistoria hasta nuestros días, Santiago, Pehuén Editores.

Miranda, F. and A. Morales (2012), "Movimiento ciudadano: Aysén, tu problema es mi problema", S. Gómez (comp.), Santiago, University of the Academy of Christian Humanism/Agrarian Research Group.

Molenaars, N. (2006), "Associational life and local development in two Nicaraguan villages", CEPAL Review, No. 90 (LC/G.2323-P), Santiago, December.

Ostrom, E. (1990), Governing the Commons: The Evolution of Institutions for Collective Action, Cambridge, Cambridge University Press.

Pérez, M. (2014), "Movimiento social de Aysén: un caso de análisis de incidencia ciudadana en la agenda de políticas públicas", thesis, Santiago, University of Chile [online] http://www.internetycapitalsocial.cl/.

Portes, A. (1998), "Social capital: its origins and applications in modern sociology", Annual Review of Sociology, vol. 24.

Putnam, R. (1993), Making Democracy Work: Civic Traditions in Modern Italy, Princeton, Princeton University Press.

Salazar, G. (2001), "Memoria histórica y capital social", Capital social y políticas públicas en Chile, J. Durston and F. Miranda, Políticas Sociales series, No. 55 (LC/L.1606-P), Santiago, Economic Commission for Latin America and the Caribbean (ECLAC).

SUBDERE (Office of the Undersecretary for Regional and Administrative Development) (2013), "Metodología para la identificación de localidades en condición de aislamiento", Santiago [online] http://www.subdere.gov.cl/sites/default/files/documentos/ metodologia_03072013.pdf.

Tarrow, S. (1998), Power in Movement: Social Movements and Contentious Politics, Cambridge, Cambridge University Press.

Universidad de Los Lagos/Centre for Social Network Analysis (n/d), "Documentos de trabajo internos", FONDECYT Project (No. 1120866) "El impacto de Internet en el capital social de las comunidades aisladas", Santiago.

Uphoff, N. (2003), "El capital social y su capacidad de reducción de la pobreza", Capital social y reducción de la pobreza: en busca de un nuevo paradigma, Libros de la CEPAL, No. 71 (LC/G.2194-P), R. Atria and others (comps.), Santiago, Economic Commission for Latin America and the Caribbean (ECLAC).

Valenzuela, A. (1977), Political Brokers in Chile, Durham, Duke University Press.

Wellman, B. (2001), "Physical Place and Cyberplace: The Rise of Personalized Networking", International Journal of Urban and Regional Research, No. 25: 227-252.

Wolf, E.R. (1966), "Kinship, friendship and patron-client relationships in complex societies", The Social Anthropology of Complex Societies, M. Banton (comp.), London, Tavistock Publications.

Woolcock, M. and D. Narayan (2000), "Social capital: implications for development theory, research and policy", World Bank Research Observer, vol. 15, No. 2, Washington, D.C., World Bank. 